\title{
Research on the charging rules of shore power service charge in China
}

\author{
Siyuan Tang ${ }^{1}$, Yiqin $\mathrm{Li}^{2 *}$, Nannan $\mathrm{Liu}^{3}$ and Haibo $\mathrm{Li}^{4}$ \\ 1, 2,3,4 China Waterborne Transport Research Institute, Beijing, 10088, China
}

\begin{abstract}
Firstly, this paper defines the definition and attribute of shore power service charge, and combs the current situation of shore power service charge and electricity charge in China. At the same time, the paper analyses the cost of shore power service, electricity charge of the power supply department and the cost of ship's using fuel oil for self-generation, and makes a comprehensive comparison between the cost of ship's using shore power and the cost of ship's self-generation. Finally, according to the principle of ensuring that the cost of using shore power (shore power service charge plus electricity charge) is lower than the cost of self-generation for ships, the paper puts forward suggestions that the shore power service charge should be collected according to the power usage and the government should issue guidance prices.
\end{abstract}

\section{Introduction}

The use of shore power for ships refers to the use of clean energy provided by the port to supply power to the main shipboard system when berthing ships close their own auxiliary generators, which is a more environmentally friendly way of ship energy supply. In addition to the construction cost, the long-term use cost of shore power facilities is higher. At present, there is a great difference in the form and amount of charge for shore power service, which is not conducive to the use and promotion of shore power. For this situation, in order to improve the enthusiasm of using shore power for ships, relevant subsidy policies and government guidance prices of shore power service charge should be studied.

\section{Definition and attribute of shore power service charge}

Shore power service charge is the cost of shore power operation and maintenance charged by the port, with the unit of yuan / $\mathrm{kWh}$. It is a part of the cost of ship's using shore power, mainly including the purchase cost of shore power equipment for port investment and construction, shore power operation and labor cost, operation income, etc. This paper does not consider the part of operating income in the analysis. The cost of ship's using shore power includes shore power service charge and electricity charge.

Port shore power facilities are generally built at the front of the terminal and invested by the port enterprise or the third party authorized by the port enterprise. Each berth is generally equipped with only one set of shore power equipment. If the ship docked at the terminal need to use shore power, there is no other shore power equipment to choose from. Therefore, the shore power service charge is not formed through market competition, and government guidance prices should be issued for the charge.

\section{Current situation of shore power service charge and electricity charge in China}

\subsection{Local government stipulates the guidance price for ship's using shore power, and subsidizes the difference between the guidance price and the actual cost}

In this case, local government stipulates the guidance price for ship's using shore power charges collected by port enterprises from ships, which is significantly lower than the cost of ship's self-generation, and also lower than the electricity charge of the power supply department. The government subsidizes the difference between the cost of ship's using shore power and the electricity charge of the power supply department. And the government has a separate subsidy for port maintenance fees, which guarantees the interests of both port enterprises and shipping enterprises. At present, Shenzhen, Shanghai, Xiamen and Guangzhou all adopt this charging mode.

\subsection{Local government issues the rules for the charges for ship's using shore power}

Jiangsu Province issued the shore power policy document, which stipulates that shore power is exempt from basic electricity charge and the local price control departments should issue the charging rules for ship's

*Corresponding author's e-mail: liyq@wti.ac.cn 
using shore power. The charging rules shall be based on the above electricity charge plus the shore power service charge (port maintenance charge).

\subsection{Port enterprise independently determine the charge for ship's using shore power}

Zhejiang Province, Hubei Province, Qingdao city and other local governments issued documents which state that the shore power service charge (belonging to the ship supply service charge) is subject to market adjustment price, which is independently determined by the port enterprise according to the market.

In addition, due to the initial stage of using shore power, many ports have not yet started to charge for ship's using shore power.

Table 1. Cost calculation of shore power service of coastal port enterprises.

\begin{tabular}{|c|c|c|c|}
\hline & & One set & Three sets \\
\hline \multirow[t]{2}{*}{ Construction cost } & Facilities (yuan / year) & 411,667 & $1,235,001$ \\
\hline & Buildings (yuan / year) & 83,333 & 249,999 \\
\hline $\begin{array}{l}\text { Operation and } \\
\text { maintenance cost }\end{array}$ & $\begin{array}{l}\text { Safety test, typhoon prevention and flood control, } \\
\text { reimbursement, labor (yuan / year) }\end{array}$ & 952,214 & $1,285,214$ \\
\hline Financial cost & Loan fee, $5.9 \%$ interest (yuan / year) & 472,000 & $1,416,000$ \\
\hline Taxes & (yuan / year) & 116,008 & 253,037 \\
\hline Total cost & (yuan / year) & $2,035,222$ & $3,014,930$ \\
\hline \multirow[t]{3}{*}{$30 \%$ usage rate } & Annual average power usage of ships $(\mathrm{kWh})$ & $1,619,200$ & $4,857,600$ \\
\hline & $\begin{array}{l}\text { Cost of shore power service considering equipment } \\
\text { investment (yuan } / \mathrm{kWh} \text { ) }\end{array}$ & 1.26 & 0.91 \\
\hline & $\begin{array}{l}\text { Cost of shore power service without considering } \\
\text { equipment investment (yuan } / \mathrm{kWh} \text { ) }\end{array}$ & 0.62 & 0.28 \\
\hline \multirow[t]{3}{*}{$100 \%$ usage rate } & Annual average power usage of ships $(\mathrm{kWh})$ & $5,399,654$ & $16,198,963$ \\
\hline & $\begin{array}{l}\text { Cost of shore power service considering equipment } \\
\text { investment (yuan } / \mathrm{kWh} \text { ) }\end{array}$ & 0.38 & 0.27 \\
\hline & $\begin{array}{l}\text { Cost of shore power service without considering } \\
\text { equipment investment (yuan } / \mathrm{kWh} \text { ) }\end{array}$ & 0.19 & 0.08 \\
\hline
\end{tabular}

As can be seen from Table 1, if the scale of shore power increases (for example, increase to three sets), the average labor cost will be reduced, and the total service cost will be correspondingly reduced. The range of shore power service cost under the above calculation model is $0.08 \sim 1.26$ yuan / kWh.

\subsubsection{Cost analysis of shore power service of inland port enterprises}

\section{Cost analysis of using shore power}

\subsection{Cost analysis of shore power service of port enterprises}

\subsubsection{Cost analysis of shore power service of coastal port enterprises}

Taking a container terminal with a shore power capacity of 3MVA as an example, considering the investment and operation cost, this paper analyzes the cost of shore power service of coastal port enterprises, as shown in Table 1.

Taking inland dry bulk terminal and cruise terminal as examples, this paper analyses the cost of shore power service of inland port (Table 2). Among them, the shore power of dry bulk terminal is low-voltage 400kVA fixed shore power, which can meet the needs of 10000 ton ships. The shore power of cruise terminal is used for $7500 \mathrm{kVA}$ floating terminal, which can provide power for 6 barges and 12 berths of 10,000 ton ships at the same time.

Table 2. Cost of shore power service of inland port enterprises.

\begin{tabular}{llll}
\hline & & $\begin{array}{l}\text { Dry bulk } \\
\text { terminal }\end{array}$ & Cruise terminal \\
\hline Construction cost & Equipment (yuan / year) & 77,000 & $2,284,200$ \\
& Buildings (yuan / year) & 10,000 & 74,300 \\
\hline
\end{tabular}




\begin{tabular}{|c|c|c|c|}
\hline $\begin{array}{l}\text { Operation and } \\
\text { maintenance cost }\end{array}$ & $\begin{array}{l}\text { Safety test, typhoon prevention and flood control, } \\
\text { reimbursement, labor (yuan / year) }\end{array}$ & 280,500 & $1,470,750$ \\
\hline Financial cost & Loan fee, $5.9 \%$ interest (yuan / year) & 102,660 & $2,783,030$ \\
\hline Taxes & (yuan / year) & 28,419 & 399,682 \\
\hline Total cost & (yuan / year) & $2,035,222$ & 498,579 \\
\hline \multirow[t]{3}{*}{$30 \%$ usage rate } & Annual average power usage of ships $(\mathrm{kWh})$ & 103,478 & $2,365,200$ \\
\hline & $\begin{array}{l}\text { Cost of shore power service considering equipment } \\
\text { investment (yuan } / \mathrm{kWh} \text { ) }\end{array}$ & 4.82 & 2.96 \\
\hline & $\begin{array}{l}\text { Cost of shore power service without considering } \\
\text { equipment investment (yuan / } \mathrm{kWh} \text { ) }\end{array}$ & 2.61 & 0.34 \\
\hline \multirow[t]{3}{*}{$100 \%$ usage rate } & Annual average power usage of ships $(\mathrm{kWh})$ & 344,925 & $7,884,000$ \\
\hline & $\begin{array}{l}\text { Cost of shore power service considering equipment } \\
\text { investment (yuan } / \mathrm{kWh} \text { ) }\end{array}$ & 1.45 & 0.89 \\
\hline & $\begin{array}{l}\text { Cost of shore power service without considering } \\
\text { equipment investment (yuan } / \mathrm{kWh} \text { ) }\end{array}$ & 1.10 & 0.10 \\
\hline
\end{tabular}

It can be seen that the cost of shore power service of cruise terminal is lower than that of bulk cargo terminal due to the long service time. The cost of inland dry bulk terminal is $1.10 \sim 4.82$ yuan $/ \mathrm{kWh}$, and that of cruise terminal is $0.10 \sim 2.96 y u a n / \mathrm{kWh}$.

\subsection{Analysis of electric charge of the power supply department}

The terminal electricity charge of the power supply department affects the economy of using shore power and the enthusiasm of ship's using shore power.
At present, there is a certain difference in the electricity price of each port in China (Figure 1). The general price is about $0.66 \sim 0.8$ yuan / $\mathrm{kWh}$. According to the document issued by the National Development and Reform Commission in July 2018, the capacity electricity charge is exempted for the commercial electricity of port operation. Therefore, the electricity charge of the typical port in Figure 1 will be reduced. Generally, the electricity charge of the coastal port can be calculated as $0.7 \mathrm{yuan} / \mathrm{kWh}$.

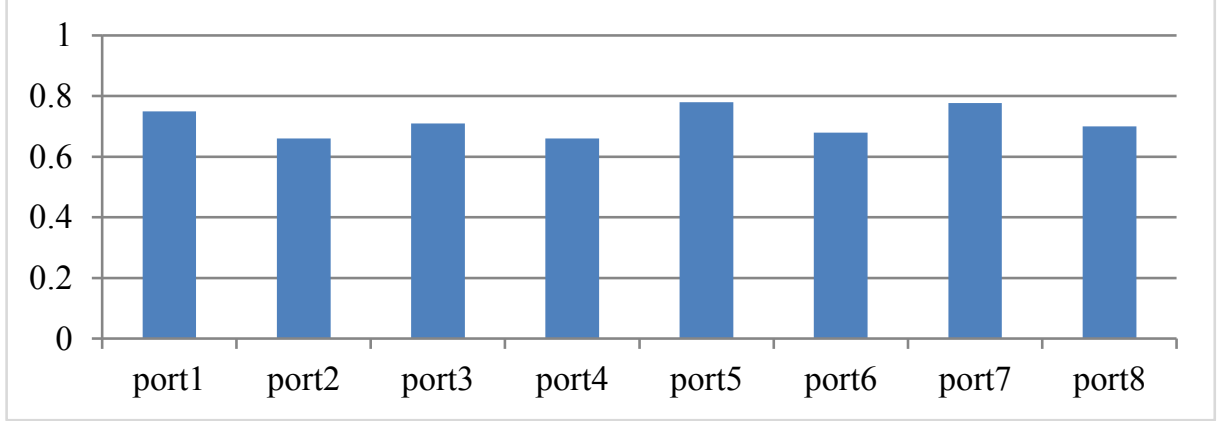

Figure 1. Electricity charges at major ports in China (unit: yuan / kWh).

According to the data of the State Grid, the electric charge in the inland river area of China is 0.6418yuan / $\mathrm{kWh}$.

\subsection{Cost analysis of ship power generation}

Considering the depreciation cost, maintenance cost and personnel cost, take the 10000 TEU container ship as an example, the calculation of the total power generation cost of the ship is shown in Table 3 . If $0.1 \%$ bonded fuel oil is used for coastal ships, the calculated total power generation cost of coastal ship is $1 \sim 1.48$ yuan / $\mathrm{kWh}$. Ordinary diesel oil can be used for inland ships, and the calculated total power generation cost of inland ship is 1.76 2.63yuan / kWh.

Table 3. Price of ship fuel oil and cost of power generation.

\begin{tabular}{|c|c|c|c|c|}
\hline Oil category & $\begin{array}{l}0.1 \% \mathrm{~b} \\
\text { oil }^{\mathrm{a}}\end{array}$ & $\begin{array}{l}10.5 \% \text { domestic } \\
\text { trade ship fuel oil }\end{array}$ & $\begin{array}{l}\text { 180CST } \\
\text { fuel oil }\end{array}$ & $\begin{array}{l}\text { Diesel oil for } \\
\text { inland ships }\end{array}$ \\
\hline Fuel oil price (yuan / t) & 3,800 & 4,800 & 4,637 & 7,000 \\
\hline Fuel oil fee ${ }^{b}$ & 0.89 & 1.13 & 1.09 & 1.65 \\
\hline
\end{tabular}

(yuan / kWh, e = 235g / kWh) 


$\begin{array}{lllll}\begin{array}{l}\text { Fuel oil fee } \\ \text { (yuan / kWh, e }=360 \mathrm{~g} / \mathrm{kWh} \text { ) }\end{array} & 1.37 & 1.69 & 1.67 & 2.52 \\ \begin{array}{l}\text { Depreciation cost of generator unit } \\ \text { (yuan / kWh) }\end{array} & 0.06 & 0.06 & 0.06 & 0.06 \\ \begin{array}{l}\text { Maintenance and personnel cost (yuan / } 0.05 \\ \mathrm{kWh} \text { ) }\end{array} & 0.05 & 0.05 & 0.05 \\ \begin{array}{l}\text { Total power generation cost of ship } \\ \text { (yuan / kWh) }\end{array} & 1.0 \sim 1.48 & 1.24 \sim 1.84 & 1.2 \sim 1.78 & 1.76 \sim 2.63\end{array}$

a Singapore Platts marine oil price.

${ }^{\mathrm{b}} \mathrm{C}=\mathrm{e} \mathrm{P} / 10^{6}$.

C_- Fuel oil cost for ship power generation, yuan / $\mathrm{kWh}$;

e-Fuel oil consumption per unit generating capacity of a ship, g / kWh;

$\mathrm{P} \_$Price of ship fuel oil, yuan / $\mathrm{t}$.

\subsection{Comprehensive cost analysis}

\subsubsection{Shore power supply for coastal ships}

See Figure 2 for the comparison between the cost of shore power service in typical coastal ports and the cost of ship self-generation. If considering the investment recovery cost of port power facilities, the service cost of shore power is as high as $0.91 \sim 1.26 y u a n / \mathrm{kWh}$ when the usage rate of shore power is $30 \%$.Combined with the electricity charge of the power supply department, the cost of using shore power is much higher than the cost of self-generation. When the usage rate of shore power is $100 \%$, the service cost of shore power is reduced to $0.27 \sim 0.38$ yuan / $\mathrm{kWh}$. In addition to the electricity charge of the power supply department, the cost of shore power is roughly equivalent to the cost of self-generation of the ship.

In view of the fund incentive policy of the Ministry of Transport and the subsidy of local government, without considering the equipment investment, the cost of shore power service is about $0.28 \sim 0.62$ yuan / $\mathrm{kWh}$ when the usage rate of port shore power is $30 \%$ and cost is about $0.08 \sim 0.19$ yuan $/ \mathrm{kWh}$ if the usage rate is increased to $100 \%$.

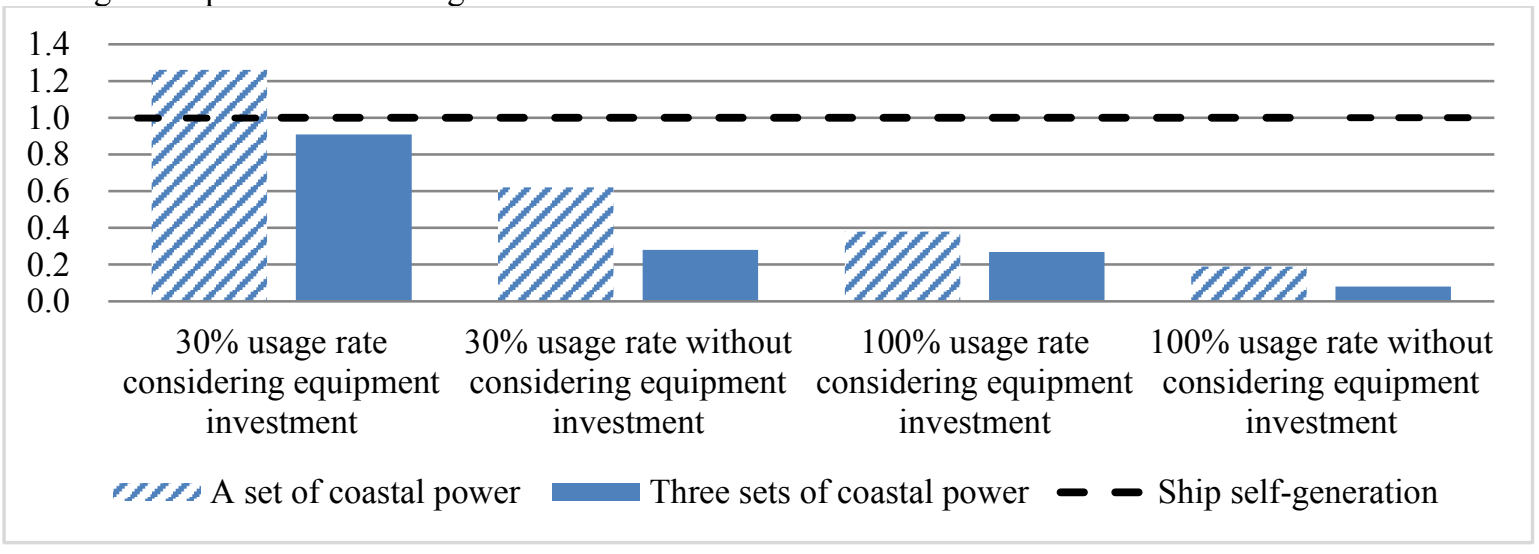

Figure 2. Comparison between the cost of shore power service and the cost of ship self-generation in Typical Coastal Ports (unit: yuan / kWh).

\subsubsection{Shore power supply for inland ships}

See Figure 3 for comparison of shore power service cost and ship self-generation cost of typical inland ports. If considering the cost of investment recovery of port power facilities, the cost of shore power for inland ships is much higher than self-generating power, when the usage rate of shore power is $30 \%$. When the usage rate of shore power is $100 \%$, the cost of shore power service of inland dry bulk terminals is reduced to 1.45 yuan $/ \mathrm{kWh}$, and the cost of shore power service of cruise terminals is reduced to 0.89 yuan $/ \mathrm{kWh}$. In addition to the electricity charge of the power supply department, the cost of using shore power for ships is roughly the same as the cost of self-generating power for ships, and the cost of cruise terminals is relatively lower.

Even considering the fund incentive policy of the Ministry of Transport and the subsidy of local government, if the equipment investment is not taken into account, the cost of shore power service of inland dry bulk terminal is about 2.61yuan / $\mathrm{kWh}$ when the actual usage rate of shore power is $30 \%$, and that of the cruise terminal is about 0.34 yuan $/ \mathrm{kWh}$. If the usage rate of shore power is increased to $100 \%$, the cost of shore power service of inland dry bulk terminal is about 1.1 yuan / $\mathrm{kWh}$, and that of cruise terminal is 0.1 yuan / $\mathrm{kWh}$. 


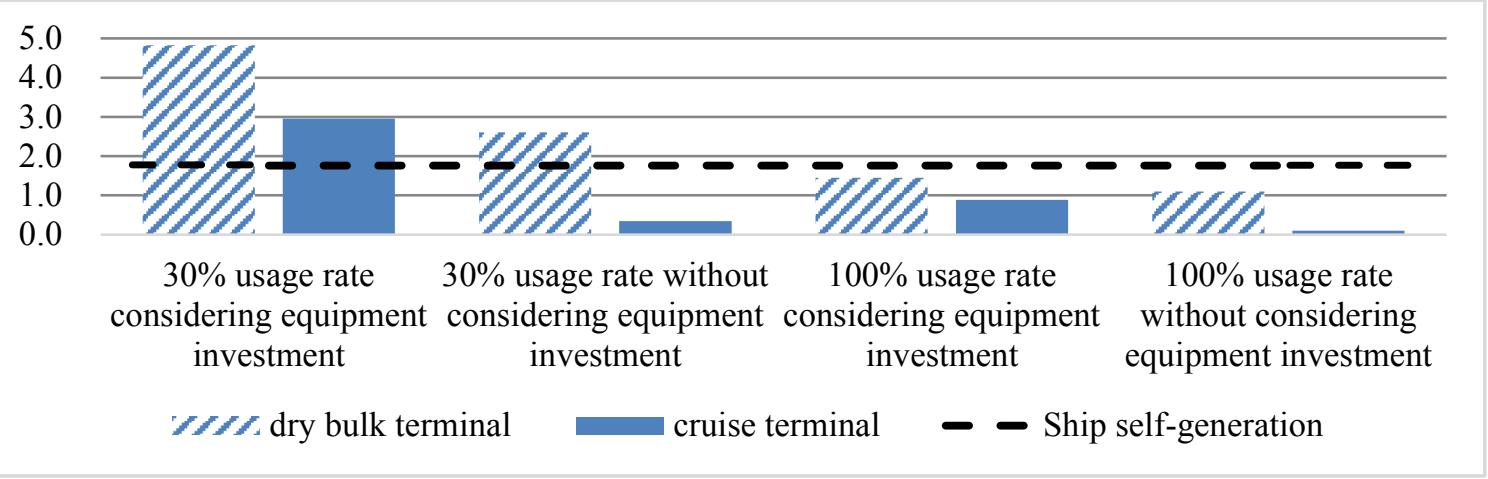

Figure 3. Comparison of shore power service cost and ship self-generation cost of typical inland ports(unit:yuan/kWh).

Due to the low power and short service time, although the investment is relatively low, the cost of shore power service is significantly higher than that of coastal power.

\section{Conclusions and suggestions on rules of shore power service charge}

The shore power service charge is greatly affected by various factors, and the price range is large under different conditions. Under the current low usage rate of shore power, shore power service cannot be charged too much. Only by encouraging ships to use shore power and taking into account the interests of both port enterprises and shipping enterprises can the use of shore power be promoted. According to the principle of ensuring that the cost of using shore power (shore power service charge plus electricity charge) is lower than the cost of selfgeneration for ships, it is suggested that the shore power service charge should be collected according to the power usage and the government should issue guidance prices.

\subsection{When the electricity charge of the power supply department higher than or equal to the cost of self-generation}

The government guidance price of shore power service charge should be set as 0.2 yuan $/ \mathrm{kWh}$.

Due to the high cost of self-generation of inland ships, this case is only applicable to the coastal shore power service charge.

\subsection{When the electricity charge of the power supply department lower than the cost of self-generation}

The government guidance price of shore power service charge shall be the difference between the cost of selfgeneration for ships and the electricity charge of the power supply department.

The cost of self-generation for coastal ships is calculated according to the MDO marine fuel oil price of Singapore Platts open market and fuel consumption rate of $235 \mathrm{~g} / \mathrm{kWh}$. The electricity charge is calculated as 0.7 yuan / kWh. According to Table 3, the cost of self- generation for ships is 1.0yuan / $\mathrm{kWh}$, then the government guidance price of shore power service charge shall be $0.3 y u a n / \mathrm{kWh}$. Under the charge price, if the usage rate of shore power reaches the best, the port can recover the investment.

The cost of self-generation for inland ships is calculated according to the price of diesel oil and fuel consumption rate of $235 \mathrm{~g} / \mathrm{kWh}$, and the electricity charge is calculated as $0.7 y u a n / \mathrm{kWh}$. According to Table 3, the cost of self-generation for ships is 1.76yuan / $\mathrm{kWh}$, then the government guidance price of the shore power service charge shall be 1.06yuan / $\mathrm{kWh}$. Under the charge price, if the usage rate of shore power reaches the best, some inland ports can recover investment and have operating income.

\section{References}

1. Feng.H., Lin.C.H., Zhang.X., Qu.Y., Tian.Y., Qi.X.Q.,Tian.Q., (2018) Economic Analysis of shore Power Operation System of Coastal Port. Port Engineering Technology., 55(2): 70-73.

2. Lai.S.H., Chen.W.W., Huang.W.T., Zheng.X., Wang.M.C., Li.D.L., (2018) Economic Analysis of Techniques. Port Engineering Technology., 53(3): 57-62.

3. Tong.Z.G., (2013) Technology and economy research on shore-side electricity system of Tianjin port. Tianjin University. Tianjin.

4. Cheng.J.L, Li.H.B., (2018) Analysis of Environmental Benefits of Shore Power for Preventing and Controlling Air Pollution Caused by Vessels at Berth. In: E3S Web of Conference.

5. Feng.Y., Li.H.B.,(2017) Study of Safety and Economy of Utilizing Shore Power Supply System for Oceangoing Ship. In: ICTIS 2017. pp. 409-413.

6. Yu.X., (2013).Environmental and economic benefits of vessels using shore-power. Shanghai: Fudan University. pp. 26-34.

7. Peng.C.S., (2012). Application and promotion of On-Shore Power Technology Served for Berthing Vessels. Port Operation. pp. 1-4. 